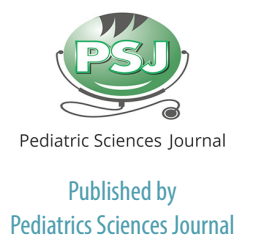

${ }^{1}$ Sangkapura Bawean Public Health Service, Bawean Island, Indonesia ${ }^{2}$ Nahdatul Ulama Tuban Hospital, Tuban, East Java, Indonesia

${ }^{3}$ Umar Mas'ud Bawean Hospital, East Java, Indonesia

${ }^{4}$ Department of Pediatrics, Medical Faculty, Universitas Brawijaya, Dr. Saiful Anwar General Hospital, Malang, Indonesia

\section{*Corrisponding to:}

Arini Haq; Sangkapura Bawean Public Health Service, Bawean Island, Indonesia arinihaqfathurrazi@gmail.com

\section{Factors affecting stunted growth in children aged 6-24 months in Bawean Island, Indonesia}

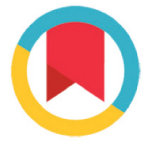

CrossMark

\author{
Arini Haq ${ }^{1 *}$, Luthfiana Eka Sari ${ }^{2}$, Pitra Sekarhandini ${ }^{3}$, \\ Brigitta Ida Resita Vebrianti Corebima ${ }^{4}$
}

\begin{abstract}
Background: Stunted is defined as a condition where body length and height are less than -2 SD of the WHO height-for-age z score. The number of stunted children worldwide reaches 129 million or $23.8 \%$ of the population. This study aims to scrutinize the factors affecting stunted growth in children aged 6-24 months old in Sangkapura district, Bawean.

Methods: This cross-sectional quantitative study in Bawean island, involving children aged 6-24 months old who came to posyandu for height measurement. The purposive sampling technique was used in the study, in which the samples filled a questionnaire consisting of several questions. The data analyses presented are univariate analysis, Chi-Square, and Binary Regression Analysis.

Results: The analysis results showed that the factors affecting stunted growth in toddlers are birth weight (<2500 grams), gestational age (<37 weeks), exclusive breastfeeding, and weaning foods. If the baby's birth weight is less than 2500 grams, is born before week 37 of pregnancy, does not get exclusive breastfeeding, and is given homemade weaning foods, the possibility of the baby being stunted is $91.5 \%$.

Conclusion: Several factors affect stunted growth in children aged 6-24 months old in Bawean island. Children who experience all of the factors mentioned above have a $91.5 \%$ possibility of being stunted. Among the other factors, babies not exclusively breastfed are 190,019 times more likely to be stunted.
\end{abstract}

Keywords: Bawean Island, Children, Factors, Stunted Growth.

Cite This Article: Haq, A., Sari, L.E., Sekarhandini, P., Corebima, B.I.R.V. 2021. Factors affecting stunted growth in children aged 6-24 months in Bawean Island, Indonesia. Pediatrics Sciences Journal 2(2): 34-37.
Received: 2021-10-21

Accepted: 2021-11-26

Published: 2021-12-01

\section{INTRODUCTION}

Stunting is defined as a condition where body length and height are less than $-2 \mathrm{SD}$ of the WHO height-for-age $\mathrm{z}$ score. ${ }^{1}$ The number of stunted children worldwide reaches 129 million or $23.8 \%$ of the population. In 2018, according to Baseline Health Research (Riskesdas), Indonesia reported the prevalence of stunting in children under two years old to be $29.9 \%$ low and $17.1 \%$ very low. The prevalence rate of stunting in East Java is 18.4\% low and $15.2 \%$ very low. ${ }^{2}$

Many stunting urges prevention, one of which is knowing the risk factors. Many factors influence the restrictions of a child's growth, such as internal and external factors, or even both. The internal factors are the basic factors of stunting, including; chronic malnutrition of the mother prior to pregnancy which is indicated by intrauterine growth restriction (IUGR), inadequate nutrient intake, and infectious diseases. $^{3-5}$ Meanwhile, the external factors influencing the nutritional status are sanitation conditions, sources of safe drinking water, economic status of the family, parents' level of education, and the number of family members. ${ }^{5,6}$

The internal factors are crucial for causing stunting, as inadequate nutrient intake during pregnancy can result in the baby experiencing intrauterine growth restriction (IUGR). ${ }^{7}$ Babies with IUGR conditions are susceptible to infections and at high risk of death. On the other hand, the babies who can survive from death tend to experience malnutrition and stunting. ${ }^{3-7}$ Exclusive breastfeeding has benefits for improving immunity. Breast milk contains macro components and micronutrients needed by babies. ${ }^{8}$ In addition, infectious diseases are also a factor causing stunted growth if it lasts for a long time. Infectious diseases with the highest morbidity rate in infants and toddlers are diarrhea and acute respiratory infection (ARI). ${ }^{9,10}$ Considering all of the factors mentioned above causing stunted growth, we would like to find out if there is a correlation between stunting and those factors.

\section{METHODS}

\section{Study Design}

This research is an analytical study that falls into observational and cross-sectional research categories. This research employs an approach, namely quantitative analysis.

\section{Sample collection and characteristics}

The research populations were taken from the Sangkapura district of Bawean island, consisting of 17 villages. The study populations were stunted children aged 6-24 months with the criteria of heightof-age less than -2 SD, and the purposive sampling technique was used in this study. The total number of samples in this study was 160 stunted and non-stunted children who got exclusive breastfeeding. 


\section{Data collection and analysis}

The data collected in this study were divided into primary and secondary data. The primary data were the stunted children, while the secondary data were collected through interviews using a questionnaire. The data analyses are done using univariate, bivariate (Chi-Square), and multivariate (Binary Logistic).

\section{RESULTS}

The study respondents were 160 children with 80 stunted children and 80 nonstunted children. Afterward, the data were analyzed using univariate, bivariate, and multivariate analysis. Univariate analysis was used to find out the respondents' characteristics: out of 160 respondents, 47 children (29.4\%) were born under 2500 grams, and 113 children (70.6\%) weighed more than 2500 grams when they were born. There were 38 children (23.8\%) born before the $37^{\text {th }}$ week of pregnancy, and 122 children $(23.8 \%)$ were born after the $37^{\text {th }}$ week. There were 87 children (54.4\%) who were exclusively breastfed and 73 children (45.6\%) who were not exclusively breastfed. The children given homemade weaning foods were 111 children (69.4\%), and those given fortified weaning foods were 49 children (30.6\%). Children whose mother was less than a high school graduate were 46 children (28.8\%), and there were 114 children (71.3\%) whose mother was a high school graduate or more. Respondents with less than three siblings were 61 children (38.1\%), and those with more than three siblings were 99 children (61.9\%). Respondents whose family income was under city minimum wage (UMK) were 85 children (53.1\%), while there were 75 children (46.9\%) whose family income was above UMK.

\section{Birth Weight}

Out of 160 respondents who were toddlers in this study, most of them were weighed more than 2500 grams at birth, there were 113 children (70.6\%), and the other 47 children weighed less than 2500 grams when they were born. Bivariate analysis was used to investigate the effect of birth weight on stunted growth status by using the Chi-Square test, with the following results (Table 1). Stunted children whose birth weights were less than 2500 grams were taller than non-stunted or normal children. Among the stunted children, $81.2 \%$ of them weighed less than 2500 grams, while there were only $60.0 \%$ of them among normal children. The ChiSquare score was 8,706 with a significance level of $0.003(p<0.05)$. In conclusion, baby birth weight significantly affected toddlers' stunted growth status.

\section{Gestational Age}

In this study, 38 babies were born before term, while the other 122 babies were born in term ( $\geq 37$ weeks). Out of 80 stunted toddlers, $37.5 \%$ were born before term or less than 37 weeks, and the other $62.5 \%$ were born $\geq 37$ weeks. Only $10 \%$ were born in less than 37 weeks among normal children. The Chi-Square test result indicated a significance level of 0.000 $(p<0.05)$. Therefore, it can be concluded that gestational age had a significant effect on toddlers' stunted growth status (Table 2).

\begin{tabular}{llllll} 
Table 1. Effect of Birth Weight on Stunted Status & & \\
\cline { 1 - 2 } \multicolumn{1}{c}{ Birth Weight } & \multicolumn{2}{c}{ Stunted } & \multirow{2}{*}{$\chi^{2}$} & P \\
\cline { 2 - 3 } & \multicolumn{2}{c}{ Yes } & No & & \\
\hline$<2500$ gram & $65(81.2 \%)$ & $48(60.0 \%)$ & & 8.706 & 0.003 \\
$\geq 2500$ gram & $15(18.8 \%)$ & $32(40.0 \%)$ & & \\
\hline
\end{tabular}

Table 2. Effect of gestational age on stunted status

\begin{tabular}{|c|c|c|c|c|}
\hline \multirow{2}{*}{ Gestational Age } & \multicolumn{2}{|c|}{ Stunted } & \multirow{2}{*}{$\chi^{2}$} & \multirow{2}{*}{$\mathbf{P}$} \\
\hline & Yes & No & & \\
\hline$<37$ Minggu & $30(37.5 \%)$ & $8(10.0 \%)$ & \multirow{2}{*}{16.704} & \multirow{2}{*}{0.00} \\
\hline$\geq 37$ Minggu & $50(62.5 \%)$ & $72(90.0 \%)$ & & \\
\hline
\end{tabular}

Table 3. Effect of exclusive breastfeeding on stunted status

\begin{tabular}{lccccc}
\hline \multirow{2}{*}{ Exclusive Breastfeeding } & \multirow{2}{*}{$\chi^{2}$} & P \\
\cline { 2 - 3 } & \multicolumn{2}{c}{ Yes } & No & & \\
\cline { 2 - 4 } Exclusive Breastfeeding & $18(22.5 \%)$ & $69(86.2 \%)$ & & 65.527 & 0.000 \\
No & $62(77.5 \%)$ & $11(13.8 \%)$ & & \\
\hline
\end{tabular}

Table 4. Effect of Weaning Food Menu on Stunted Status

\begin{tabular}{lcccc}
\hline \multirow{2}{*}{ Weaning Food Menu } & \multicolumn{2}{c}{ Stunted } & \multirow{2}{*}{ Ya } & Today \\
\cline { 2 - 3 } & $66(82.5 \%)$ & $45(56.2 \%)$ & \multirow{2}{*}{12.973} & 0.000 \\
\hline Home Made & $14(17.5 \%)$ & $35(43.8 \%)$ & & \\
\hline
\end{tabular}

\section{Exclusive Breastfeeding} (45.6\%) did not get exclusive breastfeeding. $77.5 \%$ of stunted toddlers did not get exclusive breastfeeding, and $22.5 \%$ were babies, $86.2 \%$ of them were exclusively diference The Chi-Square test result also showed a great significance level of $0.000(\mathrm{p}<0.05)$. In conclusion, exclusive breastfeeding significantly affected toddlers' stunted growth status (Table 3).

\section{Weaning Foods} their babies in society. Forty-nine toddlers were given fortified porridge or weaning foods (30.6\%), and the other 111 toddlers (69.4\%) were given homemade weaning foods. Table 4 below showed that the exclusively breastfed. Among the normal breastfed. It showed the proportion 
toddlers given homemade weaning foods were more likely to be stunted, while the toddlers given fortified porridge did not experience stunting or normal. The ChiSquare test showed a significance level of $0.000(\mathrm{p}<0.05)$, which meant that weaning foods had significant effects on toddlers' stunted growth status.

\section{Mother's Education Level}

Mothers' education levels in this study were dominated by at least High school graduates, and there were 114 people of them $(71.3 \%)$. The other 46 people (28.7\%) were less than high school graduates. Out of 80 stunted toddlers, $38.8 \%$ of them had a mother who was less than a high school graduate, while among non-stunted toddlers, only $18.8 \%$ of them whose mother was less than a high school graduate. It showed a difference between mothers' level of education with the ChiSquare result of significance level 0.005 $(\mathrm{p}<0.05)$. It can be concluded that mothers' level of education had a significant effect on toddlers' stunted growth status.

\section{The Number of Children}

Out of 160 toddlers in this study, 61 toddlers $(38.1 \%)$ had a family with a total number of children less than three, while the other 99 toddlers $(61.9 \%)$ had a family with more than three children. Among stunted toddlers, $57(71.2 \%)$ were in a family with more than three children, and 23 others (28.8\%) were with less than three children. Meanwhile, among non-stunted or normal toddlers, 42 children (52.5) came from a family with more than three children, and 38 children (47.5\%) came from a family with less than three children. The result of Chi-Square analysis showed a significance level of $0.015(\mathrm{p}<0.05)$, thus, it can be concluded that the number of children in the family had a significant effect on toddlers' stunted growth status.

\section{Family Income}

In this study, 75 families (46.9\%) had income exceeding the UMK, and the other 85 families (53.1\%) earned less than UMK. The results of Chi-Square analysis to learn about the effect of family income on toddlers' stunted status were as follows: the majority of stunted toddlers came from a family whose income was below the UMK. At the same time, most normal toddlers came from a family whose income was more than the UMK. This Chi-Square test presented the significance level of $0.017(\mathrm{p}<0.05)$, which meant that the family income significantly affected toddlers' stunted status.

\section{Factors Affecting Stunted Growth in Toddlers}

The results of bivariate analysis using ChiSquare analysis showed that birth weight, gestational age, exclusive breastfeeding, weaning foods, mother's education level, the number of children, and the family income had significant effects on stunted status. Those seven variables were analyzed using multivariate analysis employing Binary Logistic Regression to investigate the probability of toddlers' stunting. The analysis was done by using Binary Logistic Regression resulted in; the results of Binary Logistic Regression analysis showed that from the seven variables examined in the study, the variables which had a simultaneous influence on toddlers' stunted growth status were birth weight, gestational age, exclusive breastfeeding, and weaning foods. Besides, it was shown that exclusive breastfeeding had the biggest influence on stunting compared to the other factors. The babies who were not exclusively breastfed were 190,019 times more likely to be stunted than those who were exclusively breastfed.

The equation model of logistic regression was formulated as follows:

$\mathrm{Y}=-7.180+1.704$ Birth Weight +3.448 Gestational Age + 5.247 Exclusive Breastfeeding + 3.899 Weaning Foods

The probability of toddlers experiencing stunting can be generated as:

$\mathrm{Y}=-7.180+1.704(1)+3.448(1)+5.247$ (1) $+3.899(1)$

$\mathrm{Y}=-7.180+1.704+3.448+5.247+$ 3.899

$\mathrm{Y}=7.118$

Hence, the probability number was:

$$
=\frac{1}{\left(1+2.7^{-7.118}\right)}=0
$$

In conclusion, the toddlers who weighed less than 2500 grams at birth, were born in less than 37 weeks of pregnancy, were not exclusively breastfed, and were given homemade weaning foods had a $91.5 \%$ probability of being stunted.

\section{DISCUSSION}

This study is the first to identify which factors can cause stunting in Bawean island. Short stature remains a problem in Indonesia, considering the many complications it may cause. It is proven by the decreasing number of short-statured babies in East Java-based on RISKESDAS data of 2018, compared to RISKESDAS data of $2013 .^{2}$

Out of 160 respondents, 80 subjects have heights of under -2SD on the WHO curve. Thus, in this study, most respondents have birth weights above 2500 grams, 113 toddlers (70.6\%), and the other 47 toddlers have birth weights less than 2500 grams. Related to stunting, the Chi-Square score is 8.706 with a significant level of $0.003(p<0.05)$, which can be inferred that baby birth weight has a significant effect on toddlers' stunted growth status. This study aligns with $\mathrm{Ni}$ Ketut Aryastami et al. ${ }^{7}$, which shows that underweight babies at birth are 1.74 times at higher risk of stunting than babies born with normal weight.

The labor cases before term increase the rate of low birth weight, which promotes stunting. ${ }^{11}$ In this study, we are exploring the correlation between gestational age and stunting, in which the result of the Chi-Square test reveals the significance level of $0.000 \quad(\mathrm{p}<0.05)$. Accordingly, the conclusion is that gestational age significantly affects toddlers' stunted status.

The correlation between exclusive breastfeeding and stunting in this study shows a significant level of $0.000(\mathrm{p}<0.05)$. Exclusive breastfeeding has a significant effect on toddlers' stunted growth status. It is in line with the research by Devillya Puspita Dewi, which reveals that $74.2 \%$ of toddlers are not exclusively breastfed. ${ }^{12}$ Exclusive breastfeeding from the age of 0-6 months has great benefits since breast milk improves immunity in the form of an immunoglobulin or antibody and contains some substances for neutralizing 
E.coli pathogen or any other viruses in the digestive tract. ${ }^{13}$ The result of Binary Regression analysis employed in this study shows that exclusive breastfeeding plays the most important role towards stunting, among other factors. The babies who do not get exclusive breastfeeding are 190,019 times more likely to be stunted than exclusively breastfed babies. It is in line with the study by Endang Dwi Lestari et al. ${ }^{14}$, which suggests that breast milk is a preventive factor of stunting with an OR of 0.201 . According to a study on children under five years old in Banda Aceh, children who are not exclusively breastfed are at five times higher risk of stunting compared to those who are exclusively breastfed. ${ }^{15}$

The Chi-Square test, which correlates stunted growth with the choice of weaning foods menu, displays a significance level of $0.000(\mathrm{p}<0.05)$. Homemade weaning foods have significant effects on toddlers' stunted growth status. In homemade weaning foods, there is a higher chance of unmet needs of micronutrients in children under two years old, while fortified weaning foods are guaranteed to contain at least; 50 percent-per-mille (ppm) of iron, $30 \mathrm{ppm}$ of zinc, 2,5 ppm of Vitamin B1, 4 ppm of Vitamin B2, and 2 ppm of folic acid to meet the nutritional needs. ${ }^{16}$ This is congruent with the study by Limardi Suryadi et al. ${ }^{17}$, which was conducted in Sumba, revealing a correlation between inadequate nutrient of weaning foods and stunting. The restrictions of a child's growth are caused by over early baby-led weaning, inadequate nutrient of weaning foods, and weaning patterns. Child feeding requires close monitoring on the punctuality of weaning schedule, frequency, food variant, the number of food ingredients, and the food processing. ${ }^{15}$

\section{CONCLUSION}

Factors affecting stunted growth of children aged 6-24 months in Bawean island are; the birth weight is less than 2500 grams, the labor is less than 37 weeks of pregnancy, the children do not get exclusive breastfeeding, and they are given homemade weaning foods. Children who experience all of the factors mentioned above have a $91.5 \%$ possibility of being stunted. Babies who are not exclusively breastfed are 190,019 times more likely to be stunted, among any other factors.

\section{FUNDING}

There was no financial support for tis work.

\section{CONFLICT OF INTEREST}

The authors declare no conflict of interest.

\section{AUTHOR CONTRIBUTION}

All Authors were involved in concept formulating, designing, and supervising the manuscript. All authors analyzed the data, prepared the manuscript, and agreed to this final version of the manuscript submitted to this journal.

\section{ETHICAL CONSIDERATION}

There was no ethical approval from the specific organization regarding this publication. However, we have an informed consent form signed by the patient's parents. We described to the patient our plan to publish their child's case as a case report in a scientific journal.

\section{REFERENCES}

1. World Health Organization. Interpretation Guide Nutrition Landscape Information System (NLIS). Geneva: WHO; 2010. p. 1-2.

2. Badan Penelitian dan Pengembangan Kesehatan Kemenkes RI. Laporan Hasil Riset Kesehatan Dasar (Riskesdas) Indonesia tahun 2018. Jakarta: Kemenkes RI; 2018.

3. Prendergast AJ, Humphrey JH. The stunting syndrome in developing countries. Paediatr Int Child Health. 2014;34(4):250-65.

4. Caulfield L, Richard S, Rivera J, Musgrove P, Black R. Stunting, wasting, and micronutrient deficiency disorders. 2nd ed. Disease Control Priorities in Developing Countries, editor. New York: Oxford University Press; 2006. 552-567 p.

5. Millward DJ. Nutrition, infection and stunting: The roles of deficiencies of individual nutrients and foods, and of inflammation, as determinants of reduced linear growth of children. Nutr Res Rev. 2017;30(1):50-72.

6. Fikadu T, Assegid S, Dube L. Factors associated with stunting among children of age 24 to 59 months in Meskan district, Gurage Zone, South Ethiopia: a case-control study. BMC Public Health. 2014;14(800):1-7.

7. Aryastami NK, Shankar A, Kusumawardani N, Besral B, Jahari AB, Achadi E. Low birth weight was the most dominant predictor associated with stunting among children aged 12-23 months in Indonesia. BMC Nutr. 2017;3(1):1-6.

8. American Academy of Pediatrics. Breastfeeding and the use of human milk. Pediatrics. 2012;129(3):e827-41.

9. Walker SP, Wachs TD, Gardner JM, Lozoff B, Wasserman GA, Pollitt E, et al. Child development: risk factors for adverse outcomes in developing countries. Lancet. 2007;369(January 13):145-57.

10. Dewey KG, Mayers DR. Early child growth: How do nutrition and infection interact? Matern Child Nutr. 2011;7(SUPPL. 3):129-42.

11. De B, Lin S, Lohsoonthorn V, Williams MA. Risk of preterm delivery in relation to maternal low birth weight. Acta Obstet Gynecol Scand. 2007;86(5):565-71.

12. Dewi DP. Status stunting kaitannya dengan pemberian ASI eksklusif pada balita di Kabupaten Gunung Kidul. J Med Respatiespati. 2015;10(4):60-6.

13. Nirwana AB. Kandungan dan manfaat ASI dan susu formula. Yogyakarta: Nuha Medika; 2014. $125-126 \mathrm{p}$.

14. Lestari ED, Hasanah F, Nugroho NA. Correlation between non-exclusive breastfeeding and low birth weight to stunting in children. Paediatr Indones. 2018;58(3):123-7.

15. AL Rahmad AH, Miko A, Hadi A. Kajian stunting pada anak balita ditinjau dari pemberian ASI eksklusif, MP-ASI, status imunisasi dan karakteristik keluarga di Kota Banda Aceh. J Kesehat Ilm Nasuwakes Poltekkes Aceh. 2013;6(2):169-84.

16. Kementerian Kesehatan RI. Keputusan menteri kesehatan tentang fortifikasi tepung terigu $\mathrm{NO}$ 1452/MENKES/SK/X/2003. Jakarta; 2003. p. $1-3$.

17. Limardi S, Hasanah DM, Utami NMD, Sidiartha IGL. Investigating minimum acceptable diet and infant and child feeding index as indicators of stunting in children aged 6-23 months. Paediatr Indones Indones. 2020;60(5):259-68.

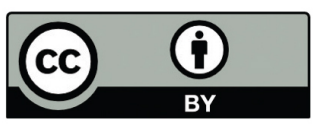

This work is licensed under a Creative Commons Attribution 